\title{
Lithofacies from the 1963-1967 Surtsey eruption in SUSTAIN drill cores SE-2a, SE-2b and SE-03
}

\author{
JOCELYN MCPHIE 1 , JAMES D.L. WHITE ${ }^{2}$, CAROLYN GORNY ${ }^{3}$, MARIE D. JACKSON ${ }^{4}$, \\ MAGNÚS TUMI GUDMUNDSSON ${ }^{3}$ AND SAMANTHA COUPER ${ }^{4}$
}

\footnotetext{
${ }^{1}$ School of Natural Sciences, University of Tasmania, Hobart, Tasmania 7000, Australia j.mcphie@utas.edu.au. (Corresponding

author). ${ }^{2}$ Geology Department, University of Otago, Dunedin 9016, New Zealand. ${ }^{3}$ Nordvulk, Institute of Earth Sciences,

University of Iceland, Sturlugata 7, 101 Reykjavik, Iceland. ${ }^{4}$ Department of Geology and Geophysics, University of Utah, Salt

Lake City, Utah, USA
}

\begin{abstract}
Surtsey was drilled in 2017 in the context of the Surtsey Underwater volcanic System for Thermophiles, Alteration processes and INnovative Concretes (SUSTAIN) project. Vertical drill holes, SE-02a and SE02b (drilled to $191.64 \mathrm{~m}$ ), and angled drill SE-03 (drilled to $354.05 \mathrm{~m}$ ), intersected armoured lapilli tuff and lapilli tuff generated mainly by explosive eruptions at Surtur from November 1963 to January 1964. The top $\sim 20 \mathrm{~m}$ of lapilli tuff was erupted from Surtungur. Intervals of coherent basalt in SE-02b (15.7 to $17 \mathrm{~m}$ and $<15 \mathrm{~cm}$ at the end) and in SE-03 $(<1 \mathrm{~m}$ at $\sim 60 \mathrm{~m}$ and $\sim 238 \mathrm{~m}$, and $10 \mathrm{~m}$ near the base) are probably intrusions that may have fed the small lavas erupted at Surtur $\sim 2.5$ years later. Although collared only a few $\mathrm{m}$ from the 1979 drill hole, neither SE-02a nor SE-02b intersected the 13-m-thick interval of basalt found in the 1979 drill hole. The 2017 drill cores are entirely lithified and variably altered, reflecting the effects of hydrothermal alteration and cement deposition on the originally fresh, unconsolidated ash and lapilli. Drill hole SE- 03 was drilled on an azimuth of $264^{\circ}$ and at $55^{\circ}$ from horizontal, obliquely crossing the crater- and conduit-fill of Surtur. Although the exact trajectory of SE-03 is unknown (the drill hole was not surveyed), the drill hole ended at a vertical depth of $\sim 100 \mathrm{~m}$ below the pre-eruption sea floor, however, sedimentary facies known to underlie the sea floor nearby were not intersected. Surtur eruptions therefore excavated the pre-eruption sea floor to a depth of several tens of $\mathrm{m}$.
\end{abstract}

\section{INTRODUCTION}

Surtsey was created by submarine and then subaerial basaltic eruptions from 1963 to 1967 (Thórarinsson et al. 1964; Jakobsson \& Moore 1982; Jakobsson et al. 2009). The eruptions began in sea water $\sim 130$ $\mathrm{m}$ deep, eventually building an island that grew to a height of $150 \mathrm{~m}$ above sea level. Two vents were active on Surtsey during the main subaerial activity. Explosive eruptions began at Surtur and lasted for about 2.5 months (visible from 14 November 1963 to 31 January 1964). Explosive eruptions then began at a second vent, Surtungur, $\sim 500 \mathrm{~m}$ to the northwest of Surtur. Explosions at Surtungur stopped on 4 April 1964, when fountains and effusion of lavas began. After a hiatus of over two months during May to July 1964, lava eruption continued at Surtungur until 17 May 1965. No further eruptions occurred 
at Surtungur. However, effusive activity resumed at Surtur in August 1966, and continued until the end of the eruption in 5 June 1967. During this period (12 December 1966 to 8 January 1967), four very small lavas, some associated with tiny spatter ramparts, were erupted from four separate vents within and on the upper outer flanks of Surtur.

In 1979, a vertical hole $181 \mathrm{~m}$ deep was drilled through the rim of Surtur (SE-01; Jakobsson \& Moore 1982, 1986), providing information on the lithofacies, structure, alteration and temperature. In 2017, the Surtsey Underwater volcanic System for Thermophiles, Alteration processes and INnovative Concretes (SUSTAIN) project, sponsored partly by the International Continental Scientific Drilling Program (ICDP), drilled three cored holes on Surtsey (Jackson et al. 2019; Weisenberger et al. 2019). Here we review the characteristics of the lithofacies in the three SUSTAIN drill holes and compare our data with those on the 1979 drill core (Jakobsson \& Moore 1982, 1986).

The four drill hole collars, SE-01 (1979) and SE02a, SE-02b, and SE-3 (2017), lie within a 10-m-wide area on the southeastern rim of Surtur (Fig. 1). The drill holes intersected eruptive products from November

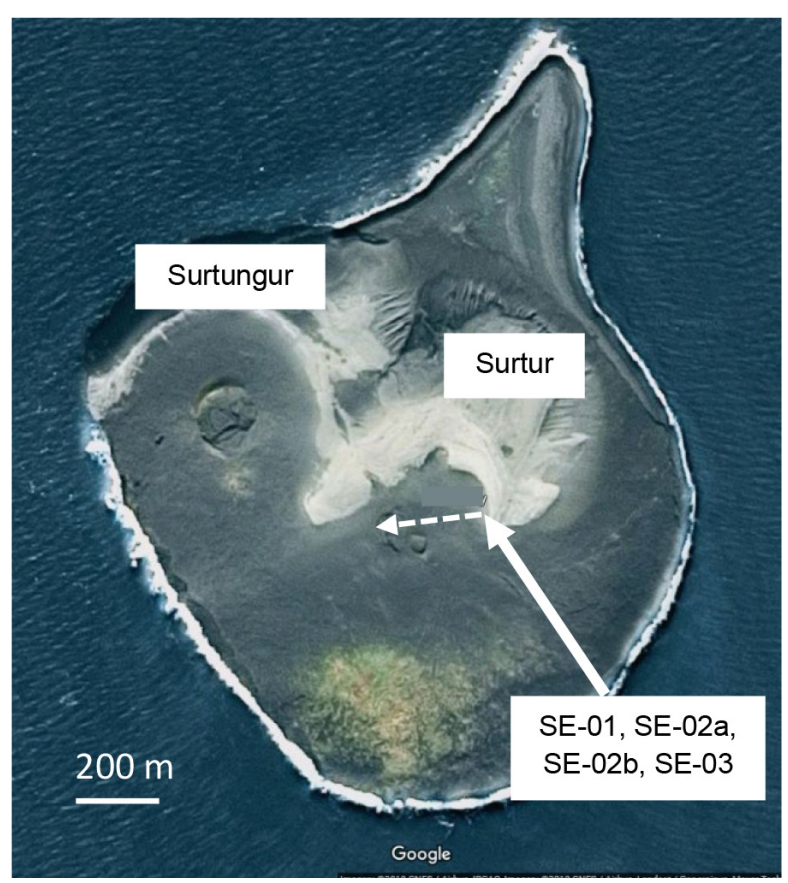

Figure 1. Map of Surtsey showing Surtungur, Surtur and the location of the drill hole collars for SE-01 (drilled in 1979) and SE02a, SE-02b and SE-03 (drilled in 2017). The white dashed line is the approximate planned trace of angled drill hole SE-03 (plunge $55^{\circ}$, azimuth $264^{\circ}$ ). Base from Google Maps.
1963 to April 1964 and slightly younger intrusions, probably emplaced 1966-1967 (Jakobsson \& Moore 1986). SE-02a is a vertical cored drill hole that was abandoned at depth $151.57 \mathrm{~m}$ following collapse. A second vertical hole, SE-02b, was then drilled adjacent to SE-02a to a depth of $191.64 \mathrm{~m}$ (recovered drill core extends to $185.85 \mathrm{~m}$ ). SE-03 is inclined, plunging $55^{\circ}$ to the west $\left(264^{\circ}\right)$ across the vent of Surtur, and extends downhole to $354.05 \mathrm{~m}$ (recovered drill core extends to $353.7 \mathrm{~m}$ ). None of the drill cores were oriented. No borehole orientation surveys were conducted on SE03 during or after drilling so the vertical thickness intersected is not exactly known but it is expected to be close to $290 \mathrm{~m}$.

\section{METHODS}

We logged the drill core from the base upward, in stratigraphic order, concentrating on textures, components, grain size and layers (Figs 2, 3). The drill core was wet when logged and the surface was intermittently moistened with sprays of fresh seawater. Most observations were made using a hand lens and, in some cases, using a binocular microscope. Data were entered into the ICDP Digital Information System (http://surtsey.icdp-online.org) and compiled as summary graphic logs, similar to those in Figures 2 and 3.

\section{PRINCIPAL LITHOFACIES}

Three main lithofacies have been defined: lapilli tuff (lithified), coherent basalt, and volcanic sandstone.

\section{Lapilli tuff}

At least $95 \%$ of the drill core consists of lapilli tuff (Fig. 4a). Weakly altered lapilli tuff is black or yellowish brown whereas more altered lapilli tuff is green, dark green or greenish black, depending on the intensity and type of alteration. In SE-02b, weakly lithified grayish black lapilli tuff (Fig. 4b, c) occupies a $<2$-m-thick section at $146 \mathrm{~m}$ depth and a 3-m-thick section close to the base (Fig. 2). These intervals are more friable and less altered than the rest. The lapilli tuff is poorly sorted, everywhere comprising components from ash $(<2 \mathrm{~mm})$ to medium lapilli (typically 8 to $10 \mathrm{~mm}$ ). Coarse lapilli (typically 4 to $6 \mathrm{~cm}$ ) are commonly present. Coarser fragments (7 to $30 \mathrm{~cm}$ ) are minor.

Lapilli tuff composed of armoured lapilli (Fig. 4d) is the dominant facies in SE-02a at four levels $(\sim 9$ to $20 \mathrm{~m}, \sim 24$ to $26 \mathrm{~m}, \sim 38$ to $40 \mathrm{~m}$ and $\sim 55$ to 66 


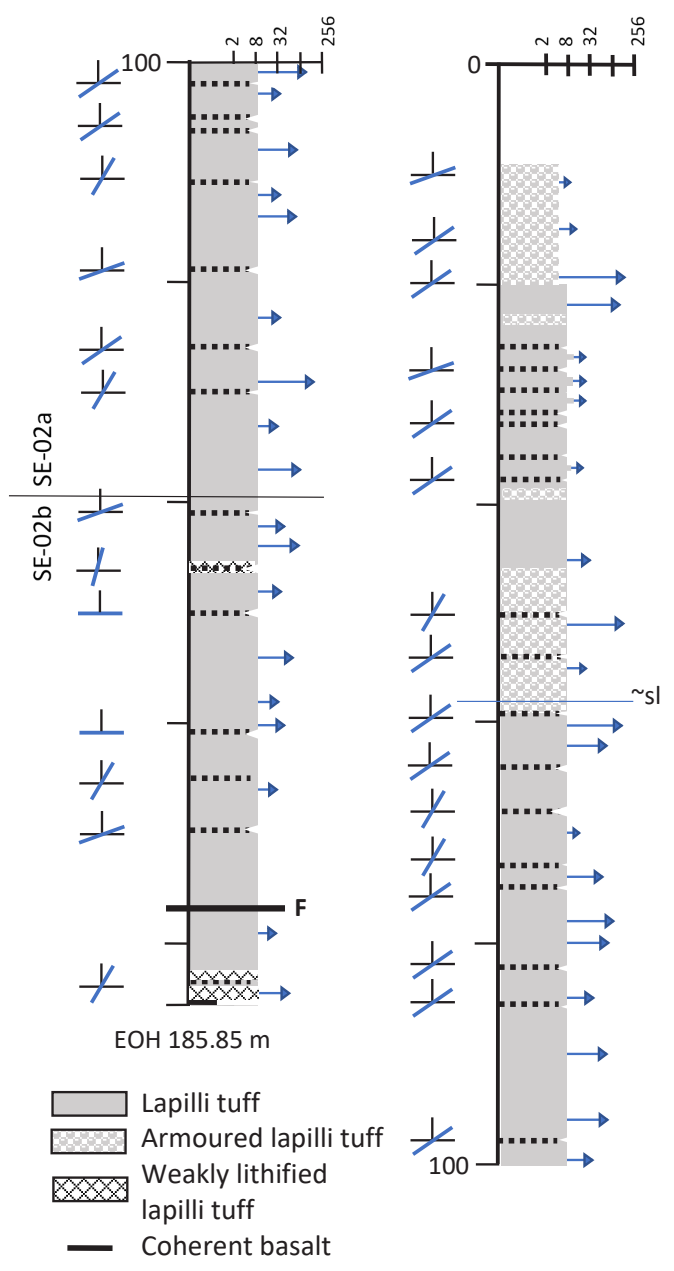

Figure 2. Simplified graphic log of the lithofacies in vertical drill holes SE-02a and SE-02b. The boundary between SE-02a (above) and SE-02b (below) occurs at $139.29 \mathrm{~m}$. The grain size scale across the top is in $\mathrm{mm}$ and depths are in $\mathrm{m}$; blue arrows give the size of the maximum clast. Beds defined by grain size differences are shown by dashed lines. Approximate orientations of beds (LHS) are given by the blue lines with respect to the drill core axis (vertical). The bold black line and " $F$ " indicate the position of a fault in the section marked by slickensides. The fine blue line is approximate sea level ( $\sim \mathrm{sl} ; \sim 58 \mathrm{~m}$ depth in the drill core). $\mathrm{EOH}$, end of recovered drill core $(185.85 \mathrm{~m})$.

m; Fig. 2) and in SE-03, at various levels above 70 m (Fig. 3). Armoured lapilli may be present in the deeper, altered parts of the drill cores but could not be confirmed using a hand lens.

\section{Coherent basalt}

Coherent basalt is a minor facies $(<4 \%$ of the stratigraphic section), occurring in SE-02b from 15.7 to $17 \mathrm{~m}$ and in the lowest $15 \mathrm{~cm}$, and in SE03 from 60.2 to $61.0 \mathrm{~m}$, between 236.3 and $238.7 \mathrm{~m}$ and from 342.4 to $352.0 \mathrm{~m}$. The basalt is dark gray,

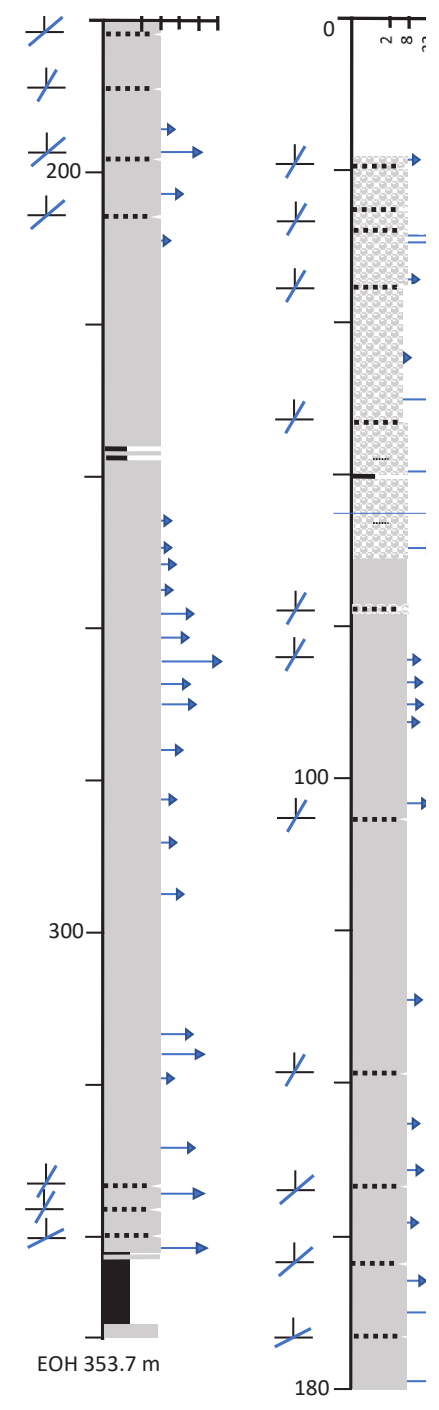

Figure 3. Simplified graphic log of the lithofacies in angled drill hole SE-03. This drill hole plunges $55^{\circ}$ toward $264^{\circ}$ but was not surveyed so the exact trajectory is not known. The legend for the patterns is given on Figure 2. The grain size scale across the top is in $\mathrm{mm}$ and depths are in $\mathrm{m}$; blue arrows give the size of the maximum clast. Beds defined by grain size differences are shown by dashed lines. Approximate orientations of beds (LHS) are given by the blue lines with respect to the drill core axis (vertical). The fine blue line is approximate sea level ( $\sim \mathrm{sl} ; \sim 65 \mathrm{~m}$ down-hole depth in the drill core). $\mathrm{EOH}$, end of recovered drill core $(353.7 \mathrm{~m})$.

vesicular, aphanitic, almost aphyric and magnetic; coarse tabular translucent feldspar crystals (3-4 mm) are present and subtle changes in vesicle abundance define subparallel mm-thick bands (Fig. 5a). In SE03, a second, weakly vesicular, feldspar-phyric basalt type is present $(\sim 347.87 \mathrm{~m}$; Fig. $5 b)$. The contacts of the basalt intervals are sharp and planar, and in some cases, clearly intrusive (e.g. Fig. 5b). 

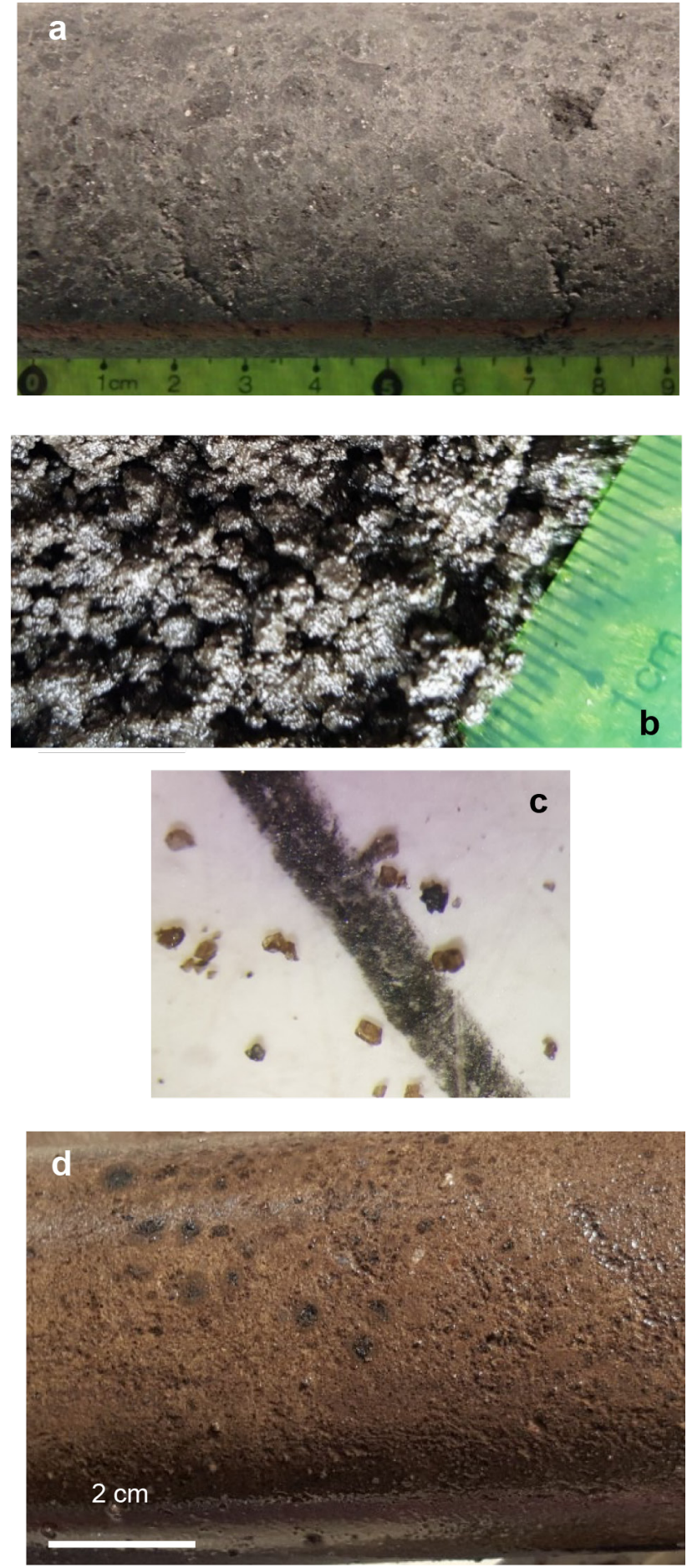

Figure 4. (a) Greenish black lapilli tuff, SE-03, $334.9 \mathrm{~m}$. Scale in cm. (b) Weakly lithified lapilli tuff, SE-02b, 185.2 m. (c) Magnified view of ash particles disaggregated from weakly lithified lapilli tuff (pencil line is $0.5 \mathrm{~mm}$ wide), SE-02b, $185.2 \mathrm{~m}$. (d) Armoured lapilli tuff, SE-02a, $9.74 \mathrm{~m}$. Drill core top to the left in (a) and (d).

\section{Volcanic sandstone}

Volcanic sandstone is the least abundant facies $(<0.1 \%$ of the section), found only in SE-03 near the base. Two layers are present (one at $339.86 \mathrm{~m}, 1 \mathrm{~cm}$
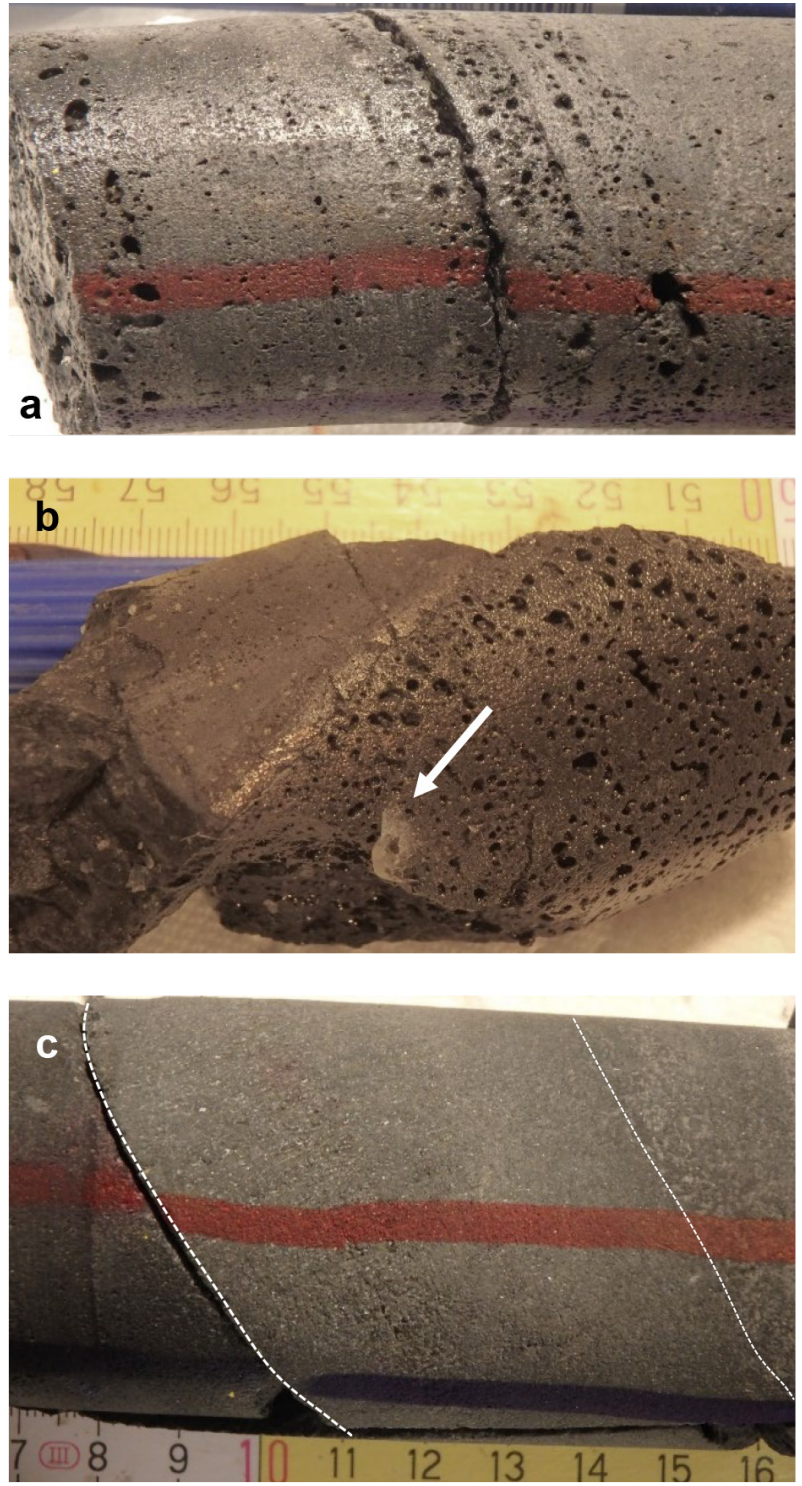

Figure 5. (a) Coherent basalt with bands of vesicles, SE-03, $350.5 \mathrm{~m}$. Drill core diameter is $6 \mathrm{~cm}$. (b) Feldspar-phyric basalt dyke (LHS) intruding aphyric vesicular basalt (RHS), SE-03, $347.87 \mathrm{~m}$. Note the coarse feldspar crystal (arrow) in the aphyric vesicular basalt. Scale in $\mathrm{cm}$. (c) Pale gray volcanic sandstone, SE-03, 349.60 to $349.65 \mathrm{~m}$. White dotted lines delineate the top and base of the sandstone; the top contact at $349.60 \mathrm{~m}$ is a fracture. Scale in cm. Drill core top is to the left in (a), (b) and (c).

thick, and the other at $349.60, \sim 5 \mathrm{~cm}$ thick; Fig. $5 \mathrm{c}$ ). Both consist of sub-mm relatively well sorted grains presumed to be volcanic. The upper layer $(339.86$ $\mathrm{m})$ is interbedded with greenish black lapilli tuff. The lower layer $(349.6 \mathrm{~m})$ separates two intervals of coherent basalt.

\section{CLAST TYPES IN LAPILLI TUFF}

The lapilli tuff consists of ash $(<2 \mathrm{~mm})$ and several different types of coarser clasts. The ash, vesicular 
lapilli, armoured lapilli and composite clasts are considered to be juvenile whereas other clast types are non-juvenile and/or have more complex origins.

\section{Ash (matrix)}

In the lapilli tuff, ash is present in varying proportions and altered to different degrees. In the weakly lithified lapilli tuff in SE-02b, the ash grains are predominantly (75-90\%) sideromelane (basaltic glass) fragments, based on their translucence and shiny appearance (Fig. 4c). Small $(<0.1 \mathrm{~mm})$ vesicles are present in coarse to very coarse ash grains $(0.5-2 \mathrm{~mm})$. Very fine to medium ash grains $(0.063-0.5 \mathrm{~mm})$ are inferred to vary in vesicularity, based on observations of the 1979 core samples. The finest components of the lapilli tuff could not be resolved with a hand lens and probably include mineral cements, especially in the more strongly altered lapilli tuff.

\section{Vesicular lapilli}

Black or dark gray, vesicular basaltic lapilli make up the main volume of the drill core (Fig. 6a). Hand lens and binocular examination of fresh vesicular lapilli indicate they are sideromelane, consistent with observations of vesicular lapilli in the 1979 drill core (Jakobsson \& Moore 1986). Vesicles are typically round and small $(<0.5 \mathrm{~mm})$, and most obvious where partly filled by white mineral cement (Fig. 6b). Within single lapilli, there are different patterns of vesicularity: (1) homogeneous, composed of a single dominant vesicle size $(\sim 0.1 \mathrm{~mm})$, with or without an additional population of smaller barely visible vesicles; and (2) banded or zoned, in which vesicles are arranged according to vesicle size, shape and abundance (Fig. 6b).

\section{Armoured lapilli}

Armoured lapilli are common in the upper one third of the drill cores. The armoured lapilli consist of a fragment of basaltic glass, commonly finely vesicular, surrounded by a rim of fine ash (Figs 4d, 6c). The ash rims are typically very thin, $\sim 1-2 \mathrm{~mm}$, though rare examples are up to $\sim 4 \mathrm{~mm}$. The visual effect of the ash rims is to prominently outline the interior clast, particularly if the central clast has vesicles filled with white mineral cements. We could not confidently identify armoured lapilli using a hand lens in the lower two-thirds of the drill cores; this part of the section is, overall, the most altered (Jackson, 2020).
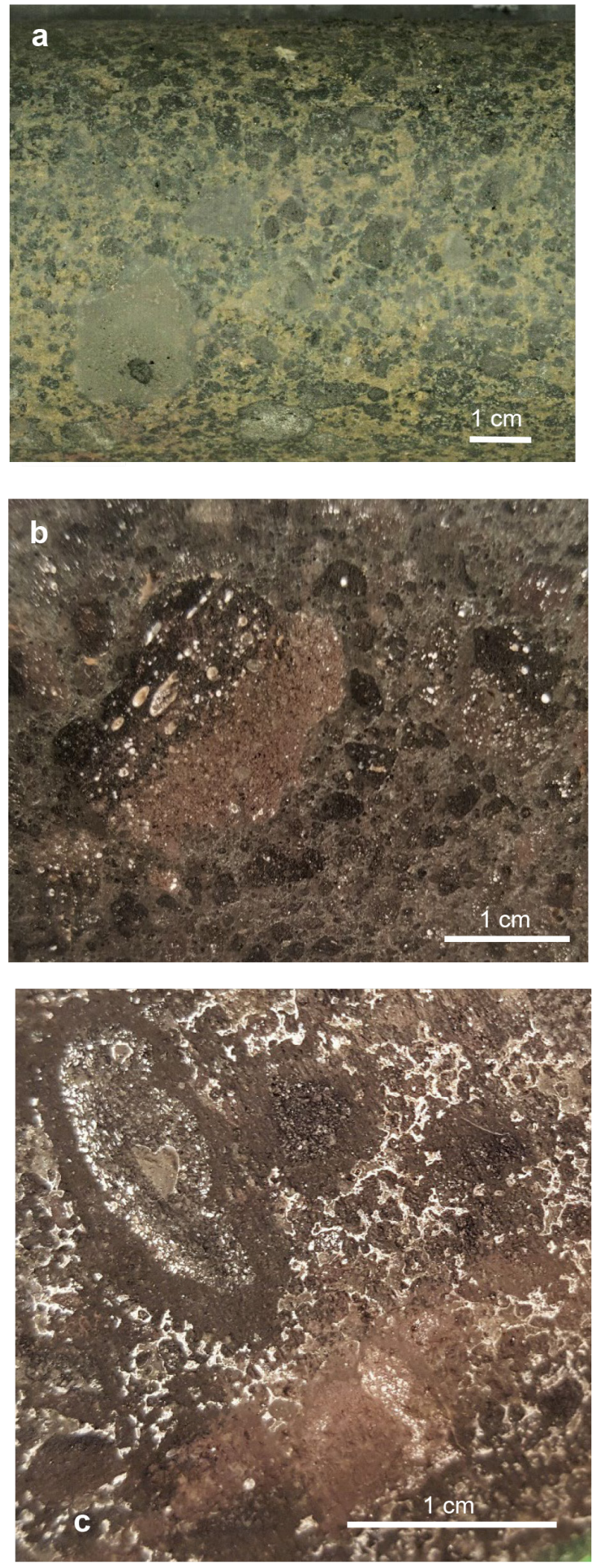

Figure 6. (a) Black, finely vesicular lapilli in weakly altered lapilli tuff, SE-03, $61.05 \mathrm{~m}$. The vesicles are round, open and $<0.5 \mathrm{~mm}$ across. (b) Vesicular lapillus in which vesicle sizes and shapes are zoned, defining bands, SE-02a, 131.5 m. (c) Armoured lapilli, SE-02a, $61.55 \mathrm{~m}$. Lapilli cores consist of brown, very finely vesicular basalt and rims are dark gray ash. 


\section{Composite clasts (lapilli and rare bombs)}

Lapilli and bombs that have a composite structure occur at all levels in the section but amount to only $\sim 10$ modal\%. "Composite" means that the clast contains, or consists of, multiple smaller clasts (Fig. 7; Schipper \& White 2016). Composite clasts typically have highly irregular shapes and consist of vesicular tachylitic (microlite-rich, basaltic) lapilli $(0.5-2.5 \mathrm{~mm})$ loosely held within a larger, less vesicular fragment. Vesicle sizes $(0.1 \mathrm{~mm}$ to $\mathrm{cms})$ and abundance ( $<10$ to $\sim 60$ modal $\%)$ within composite clasts vary widely. Fluidal layers defined by variations in vesicularity are present inside the clasts and separate different clusters of internal grains. It is notable that in altered parts of the drill cores, the composite clasts appear to be less altered and typically retain original porosity; vesicles remain open and have less secondary mineral surface coatings than adjacent altered lapilli.
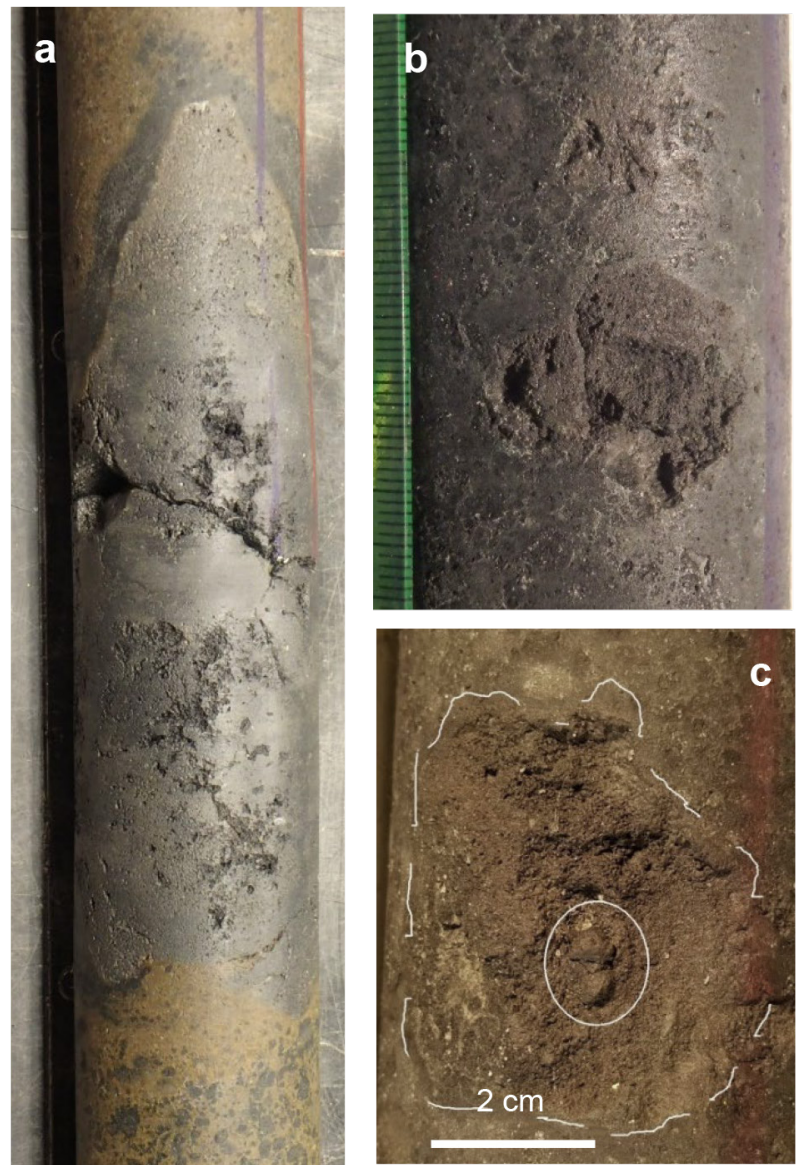

Figure 7. Composite lapilli. (a) Large composite clast $(22 \mathrm{~cm}$ in maximum length), SE-03, $59.5 \mathrm{~m}$. Drill core diameter is $6 \mathrm{~cm}$. (b) Composite lapillus in greenish black lapilli tuff, SE-03, 336.42 m. Scale in mm. (c) Composite lapillus, SE-02b, 158.95 m. Dashed outline shows the margin of the lapillus; circle encloses two distinct internal lapilli contained within the larger lapillus. Drill core top is at the top of each photo.

\section{Feldspar crystals (Labradorite)}

Translucent or white, coarse $(0.5-2 \mathrm{~cm})$ feldspar crystals (Fig. 8a) are present in low abundance $(\sim 1$ modal\%) throughout the lapilli tuff. The feldspar crystals have been identified as labradorite and their crystal structure has been defined (Steinthorsson 1965; Wenk 1985). Many crystals are broken and comprise independent grains within the lapilli tuff, but some have narrow vesicular basalt selvages.

\section{Lapilli tuff clasts}

There are rare $(<0.5$ modal\%) lapilli tuff fragments (Fig. 8b) in the lapilli tuff above a depth of about $60 \mathrm{~m}$. The particles within these clasts appear to
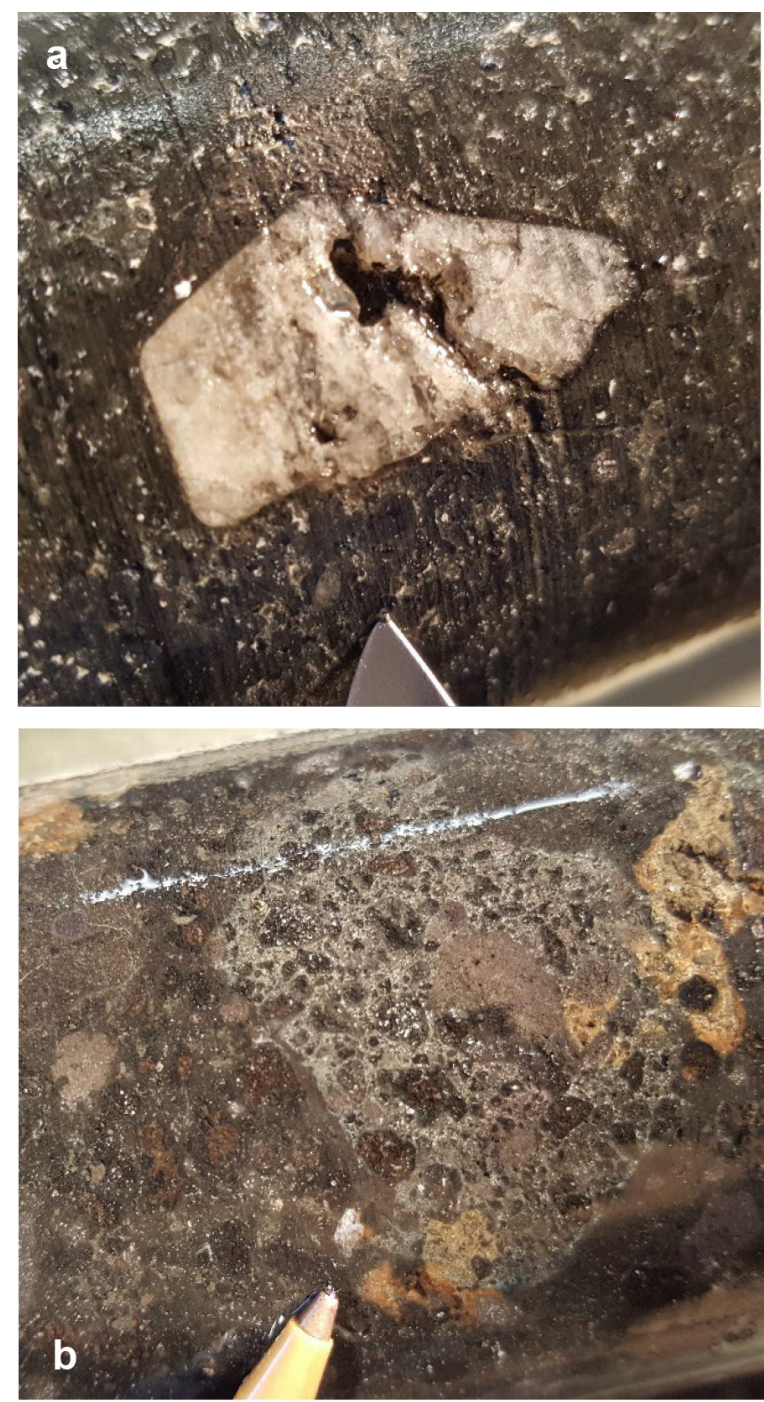

Figure 8. (a) Coarse feldspar (labradorite) crystal fragment in lapilli tuff, SE-02b, $102.84 \mathrm{~m}$. Scale is the tip of a pocket-knife blade ( $\sim 3 \mathrm{~mm}$ visible). (b) Clast of lapilli tuff, interpreted on the basis of the gray color and texture, to be intraformational, SE$02 \mathrm{a}, 43.43 \mathrm{~m}$. The host rock is lapilli tuff. Scale is the tip of a ballpoint pen. Drill core top is to the left in (a) and (b). 
be vesicular basalt, and hence are inferred to have been erupted and deposited during an earlier stage of the Surtur eruption. In one case (Fig. 8b), a white mineral cement is distinctly more abundant in the intraformational clast than in the host lapilli tuff, implying that some mineral cements were precipitated in the deeper parts of the succession before Surtur's explosive activity had ended.

\section{Dense basalt clasts}

Dark gray, aphanitic or fine-grained, non-vesicular or weakly vesicular, strongly magnetic basalt clasts (Fig. 9) are scattered through the lapilli tuff. Both rounded and angular shapes occur, and some examples contain abundant polymictic inclusions (Fig. 9b, c).
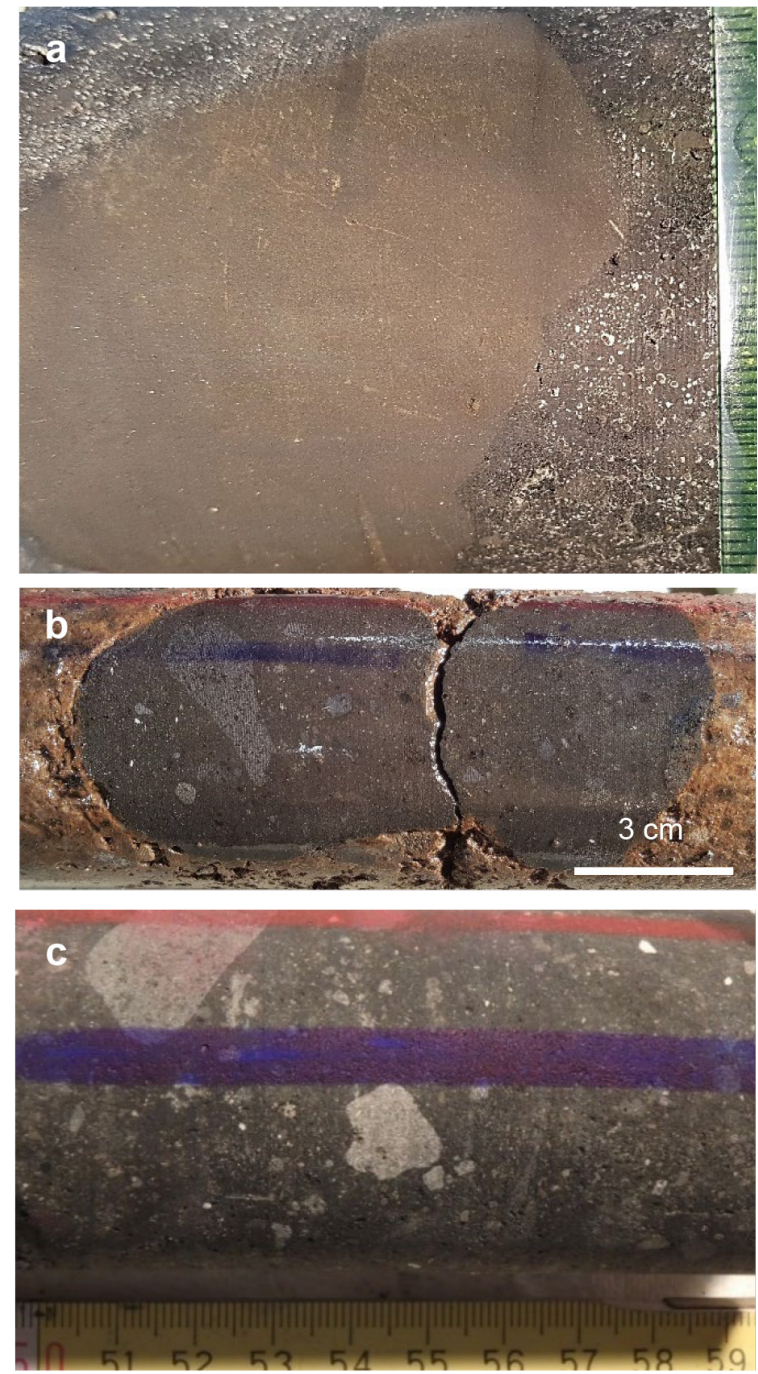

Figure 9. Dense basalt clasts in the lapilli tuff. (a) Uniformly finegrained basalt clast, SE-02a, $80.52 \mathrm{~m}$. Scale in mm. (b) Round basalt clast(s?) that contains abundant inclusions, SE-02a, 21.1 m. (c) Basalt clast (maximum dimension $11 \mathrm{~cm}$ ) that contains abundant inclusions, SE-03, $342.35 \mathrm{~m}$. Scale in $\mathrm{cm}$. Drill core top is to the left in (a), (b) and (c).

\section{Wispy fluidal clasts}

Dark gray, wispy fluidal clasts occur in the lapilli tuff in SE-03 below $250 \mathrm{~m}$ (down-hole depth). One of the best examples (Fig. 10a) has an amoeboid shape from which elongate narrow wisps only $1-3 \mathrm{~mm}$ wide extend several $\mathrm{cm}$. Although it is clear that these clasts were soft when deformed into their present shapes, their nature and origin have not been resolved.

\section{Crystalline clasts}

There are rare, rounded, holocrystalline igneous clasts in the lapilli tuff (Fig. 10b).

\section{Sedimentary clasts}

Pale gray clasts of fine-grained sandstone (Fig. 10c) are present but are very rare $(<0.5$ modal $\%)$ in the drill cores.
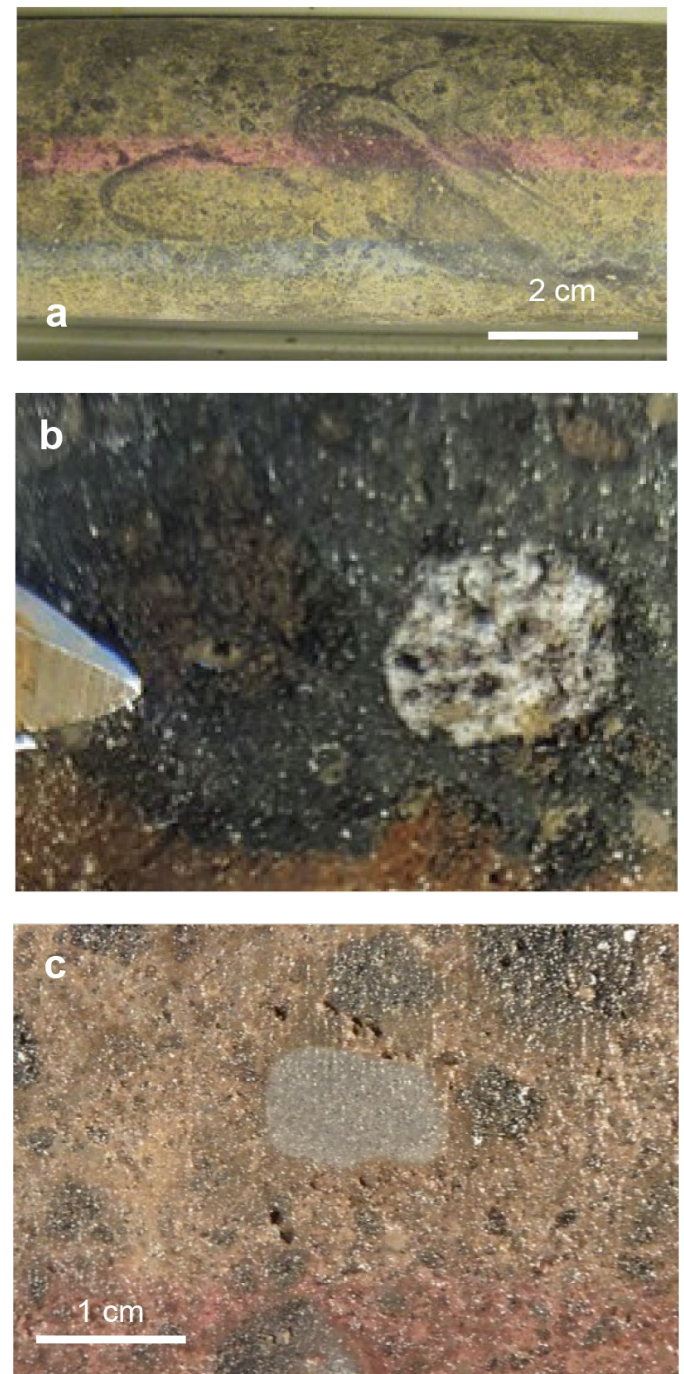

Figure 10. (a) Wispy fluidal clast in lapilli tuff, SE-03, $266.26 \mathrm{~m}$. (b) Equigranular crystalline igneous clast in lapilli tuff, SE-02a, $41.4 \mathrm{~m}$. Scale is the tip of pocket-knife blade ( $2 \mathrm{~mm}$ visible). (c) Gray fine sandstone clast in lapilli tuff, SE-02a, $14.6 \mathrm{~m}$. Drill core top is to the left in (a), (b) and (c). 


\section{BEDS AND OTHER LAYERS}

Beds defined by grain size and color differences occur throughout the drill cores but are more distinct in the less altered upper part above $\sim 70 \mathrm{~m}$, vertical depth. They are hard to discern below $\sim 150 \mathrm{~m}$, vertical depth. Bed thickness ranges from $\sim 1 \mathrm{~cm}$ to tens of $\mathrm{cm}$. A small proportion $(10 \%)$ of the beds are slightly better sorted, comprising framework-supported lapilli and minor ash; one example of a very thin, laminated ash bed was noted in SE-03 (334.3 $\mathrm{m}$ down hole).
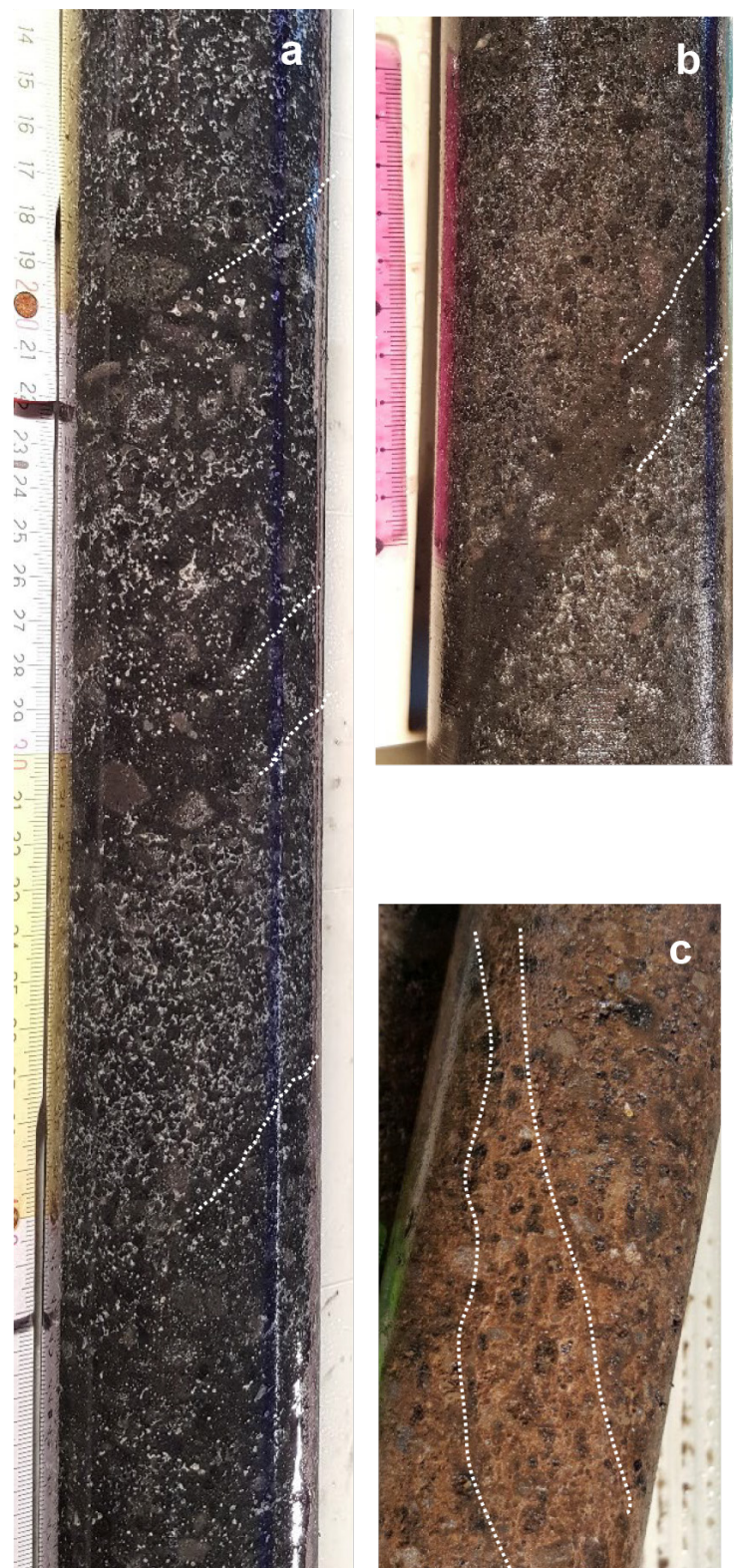

Figure 11. (a) Coarser versus finer beds in lapilli tuff, SE-02a, $82 \mathrm{~m}$. Scale in $\mathrm{cm}$. (b) Very thin, ash-rich bed in lapilli tuff, SE02a, $111.7 \mathrm{~m}$. Scale in cm. (c) Network of anastomosing, narrow cracks in lapilli tuff, SE-02a, $26.65 \mathrm{~m}$. Drill core diameter is 6 $\mathrm{cm}$. Dotted white lines in (a) and (b) highlight the beds. Dotted white lines in (c) mark the boundaries of the fracture network. Drill core top is at the top in (a), (b) and (c).
In the vertical drill holes (SE-02a, SE-02b), almost all the beds dip between $\sim 20^{\circ}$ and $60^{\circ}$ (Fig. 11a); we noted one example of almost vertical beds ( $\sim 146 \mathrm{~m}, \mathrm{SE}-02 \mathrm{~b})$ and one example of horizontal beds ( $\sim 148 \mathrm{~m}, \mathrm{SE}-02 \mathrm{~b})$. At the scale of logging used, no clear pattern in bed dip was recognised vertically through the section. Moore \& Jackson (2020) present data on bed orientations determined from unrolled digital core scans from the ICDP Digital Information System.

Very thin layers apparently defined by more abundant ash (Fig. 11b) are also present but may not be genuine beds; they may instead be either alteration artefacts or structural artefacts, such as the layers identified in Jakobsson \& Moore (1982) and Moore (1985) as shear planes. A subvertical structure $\sim 5$ $\mathrm{cm}$ wide in SE-02a (from 20 to $30 \mathrm{~m}$ and at $36 \mathrm{~m}$ ) comprises an anastomosing network of very narrow cracks (Fig. 11c).

\section{DISCUSSION}

\section{Vertical variations in lithofacies}

The main variations in grain size and components in vertical drill holes SE-02a and SE-02b (Fig. 2) are as follows:

(a) Maximum clast size (commonly $>4 \mathrm{~cm}$, some clasts 7 to $15 \mathrm{~cm}$ ) is largest between $\sim 160 \mathrm{~m}$ and $\sim 50 \mathrm{~m}$; above and below, the maximum clast size is $<4 \mathrm{~cm}$;

(b) Most vesicular basaltic lapilli from the base to $\sim 20 \mathrm{~m}$ depth are 8 to $10 \mathrm{~mm}$, coinciding with but overlapping the interval of the coarsest maximum clast sizes; in the shallowest $\sim 20 \mathrm{~m}$, most vesicular basaltic lapilli are $<7 \mathrm{~mm}$ (typically $5 \mathrm{~mm}$ );

(c) Composite clasts appear to be more abundant in the interval that contains the coarsest maximum clast sizes, between $\sim 160 \mathrm{~m}$ and $\sim 50 \mathrm{~m}$; they are also conspicuous at $\sim 18$ to $24 \mathrm{~m}$;

(d) Armoured lapilli appear to be common above $\sim 70$ $\mathrm{m}$ and are either not present, not common or not preserved below that depth.

Both Jakobsson \& Moore (1982) and Moore (1985) noted that at the 1979 drill hole site, there is a 10 - to 20-m-thick section of tephra that was erupted from Surtungur (western vent) overlying the products of Surtur (eastern vent). Moore (1985, p. 657) stated that this unconformity had not been identified in the 1979 drill core. Our log of SE-02a (Fig. 2) shows that 
the average grain size of the vesicular basaltic lapilli in the top $\sim 20 \mathrm{~m}$ is finer than in the rest of the section. The grain size change most likely corresponds to the unconformity between Surtur products below and Surtungur products above. Surtungur deposits are farther from their source vent and hence, overall finer grained than Surtur deposits.

\section{Effects of alteration in 2017 drill cores}

By alteration, we mean processes that result in changes in texture, composition, mineralogy and physical properties (density, porosity, permeability, competency). When first deposited, the subaerial tephra on Surtsey was unconsolidated, unaltered and yellowish brown or gray (e.g. Thorarinsson 1966, Figs. 18, 28 and 31). The color of the 2017 drill core varies among black, dark gray, dark greenish gray, brown, yellowish brown and pinkish brown, and all of it is altered and lithified to some extent.

In the vertical drill holes (SE-02a, SE-02b; Fig. 12), a weakly altered interval extends from the top to $\sim 54 \mathrm{~m}$ depth. This interval is lithified and mostly brown or yellowish brown (Fig. 13a) although gray patches, bands and domains are locally conspicuous (Fig. 13b, c). The black vesicular basaltic lapilli appear glassy and vesicles are only partly filled; minor white mineral cement is present. There are many examples of armoured lapilli (Fig. 4d); the textural preservation is moderate to good.

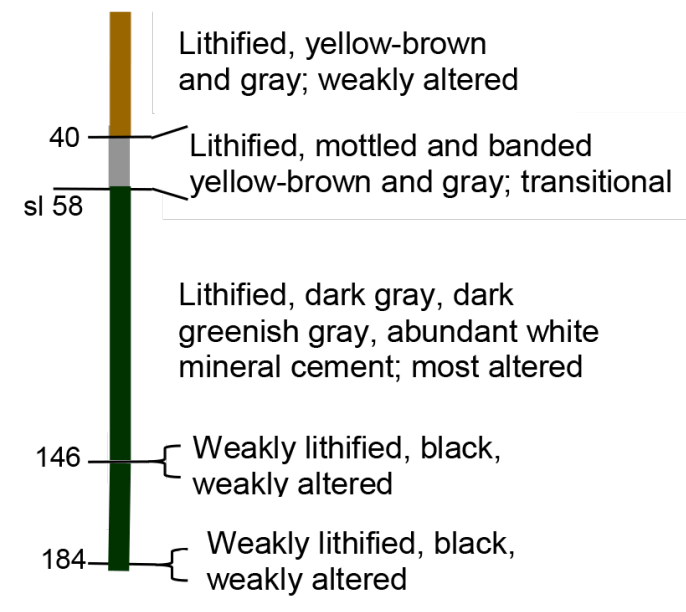

Figure 12. Schematic section showing the macroscopic vertical variations in alteration intensity in the SE-02a - SE-02b drill core. Note that the most altered lapilli tuff $(\sim 58 \mathrm{~m}$ to $\sim 182 \mathrm{~m})$ includes a weakly altered, weakly lithified interval ( 146-148 m) and overlies weakly altered, weakly lithified lapilli tuff ( $\sim 182$ $185 \mathrm{~m})$. sl, sea level.
There is a gradation into progressively morealtered lapilli tuff with depth. From $\sim 54 \mathrm{~m}$ to $\sim 70 \mathrm{~m}$, the vesicular basaltic lapilli are dull grayish black; a white mineral cement infills or lines intraparticle pores (Fig. 13d). Overall, the textural preservation is moderate and the alteration intensity is lower than in the underlying interval. From $\sim 70$ to $\sim 182 \mathrm{~m}$, the duller grayish black colour of the basaltic lapilli suggests the glass has been altered; white mineral cement is abundant and pores have been at least partially infilled (Fig. 13e). Textural preservation is moderate to poor and beds are difficult to discern. This interval is the most altered interval.

In the lowermost core retrieved from near the bottom of SE-02b ( $\sim 182$ to $185 \mathrm{~m})$, there is an abrupt change to weakly altered, weakly lithified lapilli tuff (Fig. 4c) that consists of glassy black vesicular basaltic fragments and lacks abundant mineral cement. A similarly narrow, weakly altered, weakly lithified interval occurs at 146 to $148 \mathrm{~m}$ (SE-02b; Fig. 13f).

The entire section of lapilli tuff and armoured lapilli tuff in angled drill hole SE-03 (Fig. 3) is lithified and altered. Shallower than $\sim 40 \mathrm{~m}$ (downhole depth), the lapilli tuff is tan-brown or black and weakly altered; armoured lapilli are abundant and easy to identify. From $\sim 40-65 \mathrm{~m}$, weakly altered brown-black lapilli tuff and more altered dark gray lapilli tuff are both present. Below $\sim 65 \mathrm{~m}$ (roughly equivalent to sea level), the lapilli tuff is dull and dark gray or dark greenish gray. Below $\sim 100 \mathrm{~m}$ (equivalent to $\sim 80 \mathrm{~m}$ below the surface), white mineral cement is conspicuous and armoured lapilli are either not present, not common or not preserved.

The contrast between the fresh, unconsolidated Surtsey tephra and the rock in the 2017 drill cores reflects the effects of alteration during the $\sim 50$ years since deposition. Jakobsson \& Moore $(1982,1986)$ attributed the alteration to a hydrothermal system generated by heat from basaltic dykes emplaced mainly in December 1966. Jakobsson \& Moore (1986) also concluded that there were no significant differences in the hydrothermal assemblages in the 1979 drill core above and below sea level but that the relative abundances of the minerals in the assemblages varied. Our qualitative review of the 2017 drill cores suggests that the intensity of alteration increases with depth below sea level, with the exception of the narrow weakly altered intervals in SE-02b at about $146 \mathrm{~m}$ and at the base. Fluid temperature also 

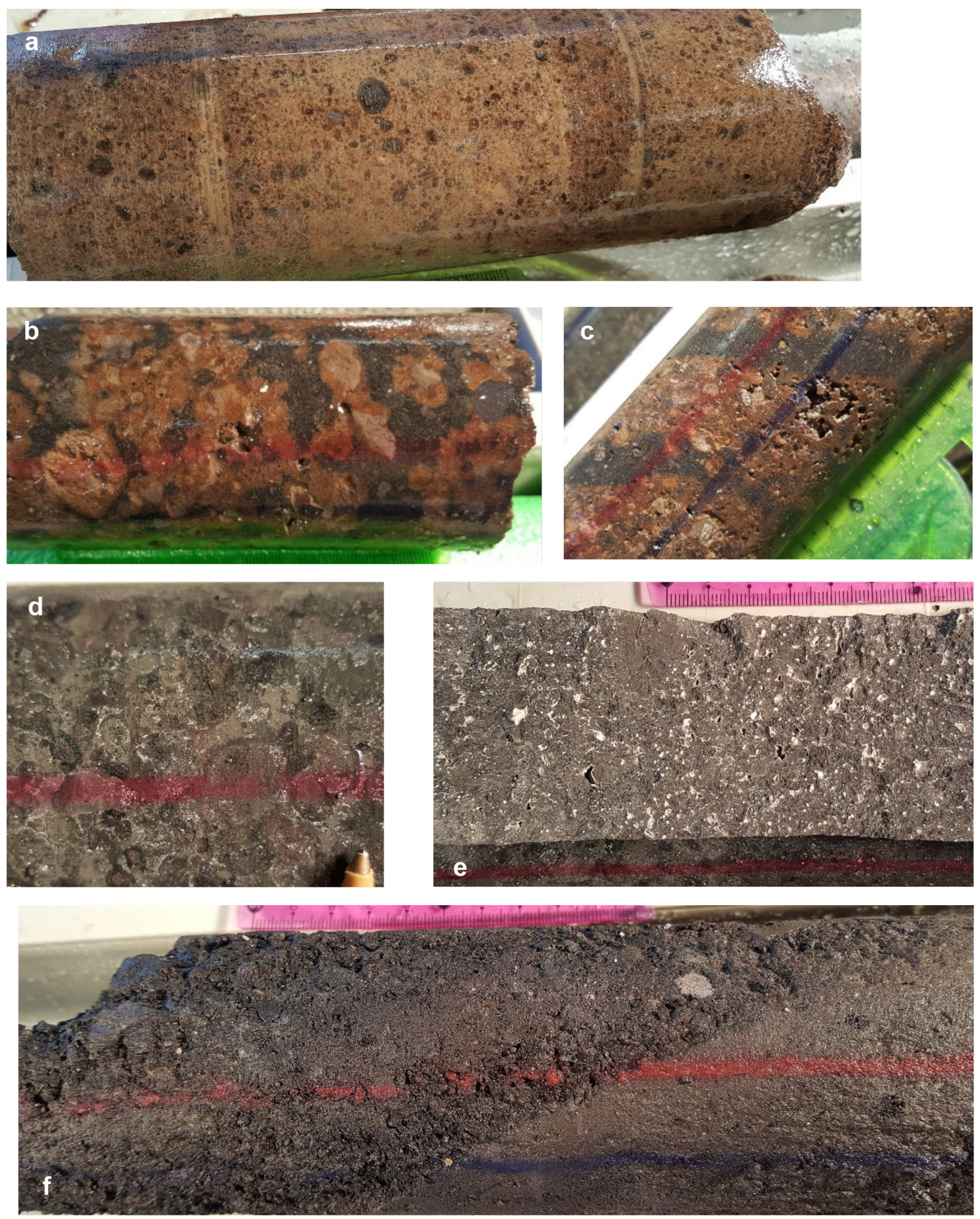

Figure 13. (a) Weakly altered armoured lapilli tuff, SE-02a, 17.4 m. (b) Weakly altered lapilli tuff composed of irregular yellowish brown versus dark gray domains, SE-02a, $41.7 \mathrm{~m}$. (c) Weakly altered lapilli tuff composed of yellowish brown versus dark gray bands, SE-02a, 36 m. (d) Mottled dark versus pale gray, altered lapilli tuff, SE-02a, $68.4 \mathrm{~m}$. White mineral cement occurs in pores. Scale is the tip of a ballpoint pen. (e) Dark gray, altered lapilli tuff with abundant white mineral cement in pores, SE-02b, 129.8 m. (f) Black, weakly altered, weakly lithified lapilli tuff, SE-02b, $146.2 \mathrm{~m}$. Note the well-defined boundary between coarser (above) and finer (below) beds. In all cases, drill core diameter is $6 \mathrm{~cm}$ and drill core top is to the left. 
increases with depth below sea level to a maximum at 40-60 m below sea level and declines at deeper levels (Jakobsson et al. 2000; Jackson et al. 2019). It is likely that being saturated with warm sea water has promoted alteration of the sub-sea-floor section.

\section{Comparison of the 2017 and 1979 vertical drill cores}

There are macroscopic similarities and differences between the geology of the 2017 vertical drill cores (SE-02a, SE-02b) and the geology of the 1979 drill core as recorded by Jakobsson \& Moore (1982). The three drill holes were collared at $\sim 58 \mathrm{~m}$ above sea level; SE-02a and SE-02b collars are about $2 \mathrm{~m}$ apart and $\sim 8 \mathrm{~m}$ from the 1979 drill hole collar.

The main similarities are:

(a) The range of dips of beds logged in the 2017 drill core is similar to that recorded by Jakobsson \& Moore (1982).

(b) In both the 1979 and 2017 drill core, the lapilli tuff is more altered below sea level ( $\sim 58 \mathrm{~m}$ depth) than above sea level.

(c)Neither the 1979 nor the 2017 vertical drill holes intersected the pre-eruption sea floor. Jakobsson \& Moore (1982) estimated the pre-1963 sea floor to be $\sim 130 \mathrm{~m}$ below sea level. The 1979 drill hole reached $180.1 \mathrm{~m}$ depth, $\sim 8 \mathrm{~m}$ above the inferred pre-1963 sea floor. The deepest drill core recovered from SE-02b at $185.85 \mathrm{~m}$ was as little as $\sim 2 \mathrm{~m}$ above the inferred pre-1963 sea floor position.

The main differences are:

(a) Coherent basalt is restricted to two thin intervals in SE-02b (15.7 to $17 \mathrm{~m}$ and the lowermost 15 $\mathrm{cm})$. In contrast, it is the dominant lithology from 71.9 to $84.8 \mathrm{~m}$ in the 1979 drill core. Jakobsson \& Moore (1982) interpreted these intervals of basalt to be dykes.

(b) In the 1979 drill core, unaltered unlithified tephra occupies more than $80 \%(\sim 35$ of $42 \mathrm{~m})$ of the section below $\sim 138 \mathrm{~m}$ to the bottom of the drill hole at $\sim 181 \mathrm{~m}$ (unaltered and unlithified from $138.1 \mathrm{~m}$ to $143.8 \mathrm{~m}, 148.5 \mathrm{~m}$ to $149.7 \mathrm{~m}, 157.4$ $\mathrm{m}$ to $168.6 \mathrm{~m}, 170.5 \mathrm{~m}$ to $180.6 \mathrm{~m}$ ) (Fig. 14). The entire section of lapilli tuff in the 2017 drill core (SE-02b) is lithified and variably altered. Weakly altered, weakly lithified lapilli tuff is restricted to the lowest few metres (below $\sim 182 \mathrm{~m}$ ) and $\sim 146 \mathrm{~m}$ to $148 \mathrm{~m} \mathrm{(} 10 \%$ of the section from $138 \mathrm{~m}$ to the end of the drill core). The weakly altered, weakly

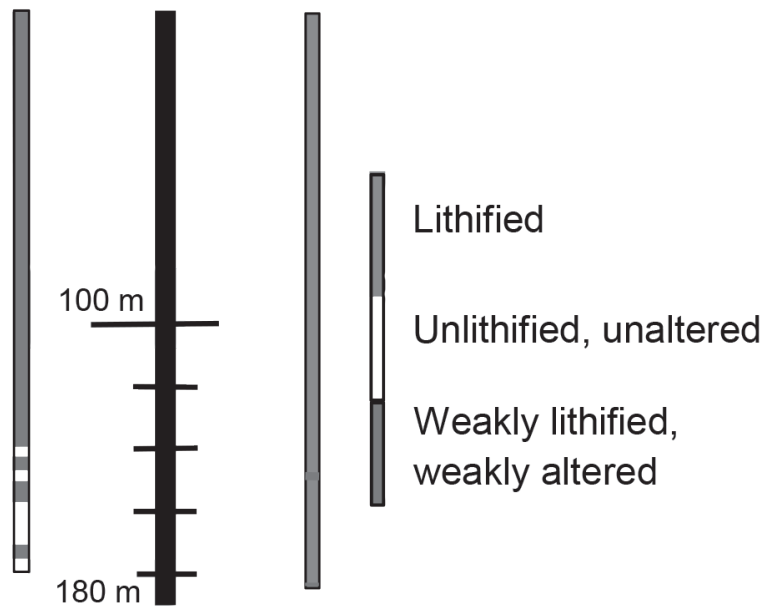

1979

2017

Figure 14. Simplified vertical distribution of lithified versus unlithified, unaltered facies in the 1979 drill core (LHS) compared with the 2017 drill core (RHS, SE-02a, SE-02b). About 20\% of the 1979 drill core is unlithified and unaltered (all below $\sim 138 \mathrm{~m}$; Jakobsson \& Moore 1982). All of the 2017 drill core is lithified and altered to some extent; $<3 \%$ is weakly lithified and weakly altered.

lithified lapilli tuff at $\sim 146 \mathrm{~m}$ in SE-02b was unaltered and unlithified in 1979. The reduction in the amount of unlithified tephra from 1979 to 2017 presumably reflects ongoing lithification through alteration of glass and crystallization of zeolite and Al-tobermorite mineral cements.

(c) Jakobsson \& Moore (1982) recorded about 50 "pre-solidification slump planes commonly associated with reworked sedimentary layers" in the section from $\sim 45 \mathrm{~m}$ to $\sim 165 \mathrm{~m}$ in the 1979 drill core. In the 2017 drill cores, layers defined by grain size changes are interpreted to be beds. A few instances of steep and/or apparently discordant beds were noted, and some of these beds might be equivalent to what were described in the 1979 core as reworked sedimentary layers associated with slumps. Other layers of uncertain origin are also present in the 2017 drill cores. Jakobsson \& Moore (1982) recorded post-solidification shear planes (13 examples from $88 \mathrm{~m}$ to $157 \mathrm{~m}$ ). Only two examples of structures interpreted to be shear-related were noted in the 2017 vertical drill core SE-2a, extending from 20 to $30 \mathrm{~m}$ and at $36 \mathrm{~m}$ (Fig. 11c), at a much shallower depth than those identified by Jakobsson \& Moore (1982). Also, these two occurrences may be connected, 
representing a single subvertical anastomosing structure.

(d) We recognise composite clasts, at low abundances, throughout the cores. Composite clasts were not previously identified in published core descriptions but have been characterized from surface deposits (Schipper \& White 2016).

The depth range of the armoured lapilli is contentious. Armoured lapilli (called "accretionary lapilli" by Jakobsson \& Moore, 1982) are discernible above $\sim 70 \mathrm{~m}$ and conspicuous above $\sim 50 \mathrm{~m}$ in SE-02a. This distribution closely matches the depth range reported by Jakobsson \& Moore (1982). However, according to Moore (1985, his Figure 6), armoured lapilli occur the full length of the 1979 drill core. Using a hand lens, we have noted possible armoured lapilli in SE02a $(119.7 \mathrm{~m})$ and SE-02b (146.5 m, $155.8 \mathrm{~m})$ but alteration has also produced "haloes" around lapilli, so confirmation that armoured lapilli are present requires examination of these samples in thin section.

The depth range of vesicular tuff is similarly contentious. Many examples of vesicular tuff (called "vesiculated tuff" by Jakobsson \& Moore, 1982) were observed in the 1979 drill core above $34.2 \mathrm{~m}$, and they have been recorded in the subaerial tephra on Surtsey (Lorenz 1974). However, Moore (1985, his Figure 6) indicated that vesicular tuff occurs the full length of the 1979 drill core. Interstitial void space is common in the lapilli tuff and armoured lapilli tuff in the 2017 vertical drill cores (e.g., Figs $6 \mathrm{c}, 13 \mathrm{e}$ ). The most obvious examples are partly lined by white mineral cement. In some cases, the voids appear to be spaces between armoured lapilli. However, much of the section that includes well-preserved armoured lapilli lacks voids or else the voids are not obviously confined to spaces between armoured lapilli. Voids are also present in more strongly altered drill core in which armoured lapilli cannot be identified in hand sample with confidence.

Moore (1985) interpreted the depth distribution of the armoured lapilli and vesicular tuff to mean that the section below sea level was in fact originally emplaced subaerially and was later moved to below-sea-level positions by inward slumping of the crater walls. Indeed, Moore (1985, his Figure 9) considered the entire section of lapilli tuff in the 1979 drill hole to consist of down-dropped beds that were originally deposited subaerially.

\section{SE-03 and Surtur crater- and conduit-fill}

SE-03 was drilled to explore the crater- and conduitfill of Surtur and perhaps help constrain the depth excavated into the pre-Surtsey sea floor by the 1963 to 1964 explosions. Because no borehole survey was conducted, the amount of deviation from the plan and the exact trajectory of SE-03 are not known. The section in SE-03 comprises texturally uniform, variably altered, lithified lapilli tuff for some 342 $\mathrm{m}$ of the total drilled length of $\sim 354 \mathrm{~m}$ (97\%). This continuous section of lithified lapilli tuff presumably originated as unconsolidated pyroclastic deposits that formed Surtur crater walls and that filled the crater and conduit. In such a proximal setting, it is likely that the section almost entirely comprises facies resedimented from unstable depositional sites and/ or recycled through the vent perhaps multiple times. SE-03 appears to include much thicker massive intervals compared with SE-02a and SE-02b (Figs $2,3)$, possibly because the complex intra-crater depositional processes favoured preservation of thick massive beds, and/or because more intense alteration in this more proximal setting has obliterated layers, and/or because the inclined drill hole obliquely crossed dipping beds at a low angle. Although not shown on the logs, the composite clasts in SE-03 appear to be smaller and less abundant than in SE02a and SE-02b. These relatively fragile clasts would have been easily destroyed by re-cycling through the vent and repeated intra-crater slumping events.

The most significant lithofacies change in SE-03 is the appearance of thick coherent basalt just above the end of the drill hole ( $\sim 342$ to $352 \mathrm{~m}$ ) and much thinner intervals at two shallower levels ( $\sim 60 \mathrm{~m}$ and $\sim 238$ m; Fig. 3). At least two feeder dykes are evident in the thick coherent basalt interval. These dykes intruded the deepest part of the lapilli tuff section, consistent with the expectation that the end of this drill hole crossed Surtur's conduit.

The pre-Surtsey sea floor was $\sim 130$ m below sea level (Jakobsson \& Moore 1982) and underlain by volcanogenic sedimentary rocks (Alexandersson 1970). Although the exact vertical depth of the end of SE-03 is not known, the planned depth of the end was $\sim 100 \mathrm{~m}$ below the pre-eruption sea floor. However, no in situ sedimentary rocks were intersected in SE03. There are three possible explanations: (1) the preSurtsey sea floor was locally deeper than $130 \mathrm{~m}$ below sea level; (2) the drill hole deviated to the extent that it ended in Surtur products above the former sea 
floor; or (3) Surtur's explosions deeply excavated the pre-Surtsey sea floor at the vent. Options (1) and (2) cannot be confirmed or eliminated but are both considered highly unlikely. The sea floor surrounding Surtsey is presently $\sim 110$ to $130 \mathrm{~m}$ deep over a radial distance of 2-3 km from the island coast, except for a narrow zone to the southeast where the sea floor reaches $139 \mathrm{~m}$ (Jakobsson et al. 2009). Regionally to the west, north and east of Surtsey, the sea floor is shallower than $130 \mathrm{~m}$ and it deepens only to $\sim 150 \mathrm{~m}$ about $10 \mathrm{~km}$ to the south (Jackson et al. 2019). Some deviation of the SE-O3 drill hole is to be expected but the deviation would have to be extreme for option (2) to be correct. If option (3) is correct, then the Surtur crater was excavated $\sim 100 \mathrm{~m}$ below the paleo-sea floor, as shown in the reconstruction in Jackson et al. (2019). It remains a puzzle that non-juvenile clasts in general, and clasts of sedimentary rock in particular, apparently amount to such a low percentage $(<5$ modal\%) of the lapilli tuff in SE-03.

\section{CONCLUSIONS}

The SUSTAIN project drilled three holes into the products of Surtsey's 1963 to1967 eruptions. Variably altered lapilli tuff composed of vesicular basaltic lapilli and ash is the most abundant lithofacies in the 2017 drill holes. Armoured lapilli are common in the sections above $\sim 70 \mathrm{~m}$ depth. All of the lapilli tuff except the top $\sim 20 \mathrm{~m}$ was erupted from Surtur during its 1963 to 1964 activity; the top $\sim 20 \mathrm{~m}$ was erupted from Surtungur in 1964. Coherent basalt occurs in two narrow intervals in SE-02b, and in two narrow $(<1.5 \mathrm{~m})$ and one thick $(\sim 10 \mathrm{~m})$ intervals in the angled drill hole, SE-03. The angled drill hole also includes very minor volcanic sandstone.

The originally unconsolidated pyroclastic deposits produced by Surtur and Surtungur were entirely lithified and variably altered when drilled in 2017. In comparison, when drilled in 1979 (Jakobsson \& Moore, 1982), $\sim 20 \%$ of the section was unlithified and unaltered. The difference reflects ongoing lithification in response to alteration of glassy components and crystallisation of mineral cements.

Although the exact depth of the end of the angled drill hole, SE-03, is not known, this drill hole ended in altered lapilli tuff intruded by basalt dykes probably several tens of $\mathrm{m}$ below the pre-eruption sea floor. None of the sedimentary rocks expected to underlie the sea floor, nor modern sediment, were intersected. Eruptive activity at Surtur must therefore have excavated to a depth of several tens of $m$ below the pre-eruption sea floor.

\section{ACKNOWLEDGMENTS}

Funding for this project was provided by the International Continental Scientific Drilling Program (ICDP) through a grant to the SUSTAIN project; a grant of excellence from the Icelandic Research Fund, ICF-RANNÍS; the Bergen Research Foundation and K.G. Jebsen Centre for Deep Sea Research at the University of Bergen, Norway; the German Research Foundation (DFG); and DiSTAR, Federico II, University of Naples, Federico II, Italy. The University of Utah, USA, the University of Tasmania, Australia, and Icelandic power companies, Reykjavík Energy and Landsvirkjun, contributed additional funds. The logistical support provided by the Icelandic Coast Guard was instrumental in carrying out the drilling operation. We gratefully acknowledge the DOSECC drilling team led by Beau Marshall with drillers Steve Cole, Justin Blouin, A. J. Vecchiarelli, Matthew Lyon, and Michael Vinson, and all members of the science and technical teams of the SUSTAIN project.

\section{REFERENCES}

Alexandersson, T., 1970. The sedimentary xenoliths from Surtsey: Marine sediments lithified on the sea-floor. A Preliminary Report. Surtsey Research Progress Report V, 83-89.

Jackson, M.D., M.T. Gudmundsson, T.B. Weisenberger, J.M. Rhodes, A. Stefánsson, B. I. Kleine, P. C. Lippert, J. M. Marquardt, H. I. Reynolds, J. Kück, V. Th. Marteinsson, P. Vannier, W. Bach, A. Barich, P. Bergsten, J. G. Bryce, P. Cappelletti, S. Couper, M. F. Fahnestock, C. F. Gorny, C. Grimaldi, M. Groh, Á. Gudmundsson, Á. Th. Gunnlaugsson, C. Hamlin, Th. Högnadóttir, K. Jónasson, S. S. Jónsson, S. L. Jørgensen, A. M. Klonowski, B. Marshall, E. Massey, J. McPhie, J. G. Moore, E. S. Ólafsson, S. L. Onstad, V. Perez, S. Prause, S. P. Snorrason, A. Türke, J. D. L. White \& B. Zimanowski, 2019. SUSTAIN drilling at Surtsey volcano, Iceland, tracks hydrothermal and microbiological interactions in basalt 50 years after eruption. Scientific Drilling, 25, 35-46.

Jakobsson, S.P. \& J.G. Moore, 1982. The Surtsey research drilling project of 1979. Surtsey Research Progress Report IX, 76-93.

Jakobsson, S. P. \& J.G. Moore, 1986. Hydrothermal minerals and alteration rates at Surtsey volcano, Iceland. Geol. Soc. Am. Bull. 97, 648-659.

Jakobsson, S.P., G. Guðmundsson \& J.G. Moore, 2000. Geological monitoring of Surtsey, Iceland, 1967-1998. Surtsey Research XI, 99-108. 
Jakobsson, S. P., K. Thors, Á.T. Vésteinsson, \& L. Ásbjörnsdóttir, 2009. Some aspects of the seafloor morphology at Surtsey volcano: The new multibeam bathymetric survey of 2007 . Surtsey Research XII, 9-20.

Lorenz, V., 1974. Vesiculated tuffs and associated features. Sedimentology 21, 273-291.

Moore, J. G., 1985. Structure and eruptive mechanisms at Surtsey Volcano, Iceland, Geol. Magazine 122, 649-661.

Schipper, C.I. \& J.D.L. White, 2016. Magma-slurry interaction in Surtseyan eruptions. Geology 44, 195-198.

Steinpórsson, S., 1965. Surtsey: Petrology and chemistry. Surtsey Research Progress Report I, 41-49.

Thorarinsson, S., 1966. Surtsey. The new island in the Atlantic. Almenna Bókafélagið, Reykjavík. 47 pp, 53 photos.

Thórarinsson, S., Th. Einarsson, G. Sigvaldason \& G. Elísson, 1964. The submarine eruption off the Vestmann Islands $1963-$ 64. Bull.Volcanol. 29, 435-455.

Weisenberger, T. B., M.T. Gudmundsson, M.D. Jackson, C. Gorny, A. Türke, B. I. Kleine, B. Marshall, S. L. Jørgensen, V. Th. Marteinsson, A. Stefánsson, J. D. L. White, A. Barich, P. Bergsten, J. G. Bryce, S. Couper, M. F. Fahnestock, H. Franzson, C. Grimaldi, M. Groh, Á. Gudmundsson, Á. Th. Gunnlaugsson, C. Hamelin, Th. Högnadóttir, K. Jónasson, S. S. Jónsson, A. Klonowski, J. Kück, R. L. Magnússon, E. Massey, J. McPhie, E. S. Ólafsson, S. L. Onstad, S. Prause, V. Perez, Velveth, J. M. Rhodes, S. P. Snorrason, 2019. Operational Report for the 2017 Surtsey Underwater volcanic System for Thermophiles, Alteration processes and INnovative Concretes (SUSTAIN) drilling project at Surtsey Volcano, Iceland. GeoForschungs Zentrum (GFZ) German Research Centre for Geosciences, 98pp.

Wenk, H.-R., W. Joswig, T. Tagai, M. Korekawa \& B.K. Smith, 1980. The average structure of An 62-66 labradorite. American Mineralogist, 65, 81-95. 